
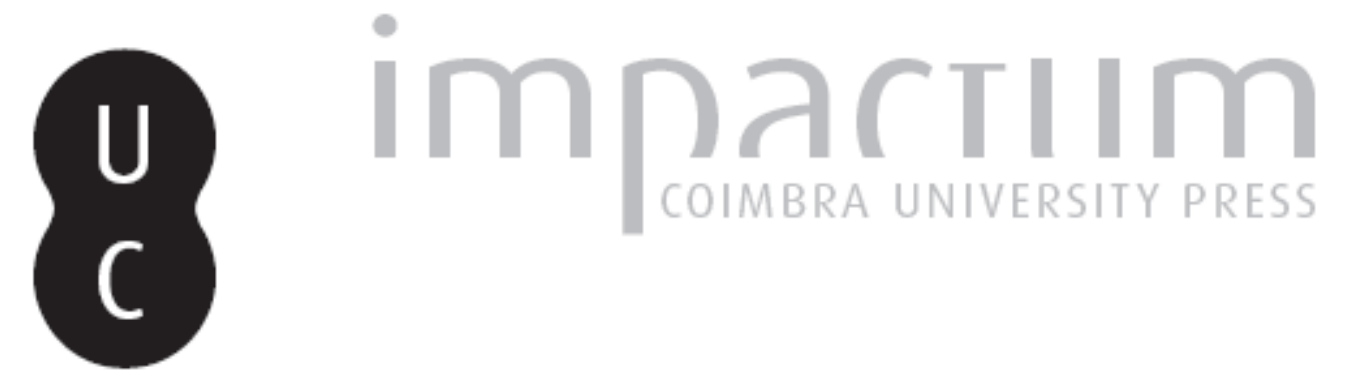

\title{
O Estado Novo e a Guerra Civil de Espanha na sociedade das nações
}

\section{Autor(es): Rosas, Fernando}

Publicado por: Imprensa da Universidade de Coimbra

URL persistente:

URI:http://hdl.handle.net/10316.2/45001

DOI:

DOI:https://doi.org/10.14195/0870-4147_38_6

Accessed : $\quad$ 26-Apr-2023 16:08:23

A navegação consulta e descarregamento dos títulos inseridos nas Bibliotecas Digitais UC Digitalis, UC Pombalina e UC Impactum, pressupõem a aceitação plena e sem reservas dos Termos e Condições de Uso destas Bibliotecas Digitais, disponíveis em https://digitalis.uc.pt/pt-pt/termos.

Conforme exposto nos referidos Termos e Condições de Uso, o descarregamento de títulos de acesso restrito requer uma licença válida de autorização devendo o utilizador aceder ao(s) documento(s) a partir de um endereço de IP da instituição detentora da supramencionada licença.

Ao utilizador é apenas permitido o descarregamento para uso pessoal, pelo que o emprego do(s) título(s) descarregado(s) para outro fim, designadamente comercial, carece de autorização do respetivo autor ou editor da obra.

Na medida em que todas as obras da UC Digitalis se encontram protegidas pelo Código do Direito de Autor e Direitos Conexos e demais legislação aplicável, toda a cópia, parcial ou total, deste documento, nos casos em que é legalmente admitida, deverá conter ou fazer-se acompanhar por este aviso.

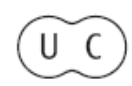



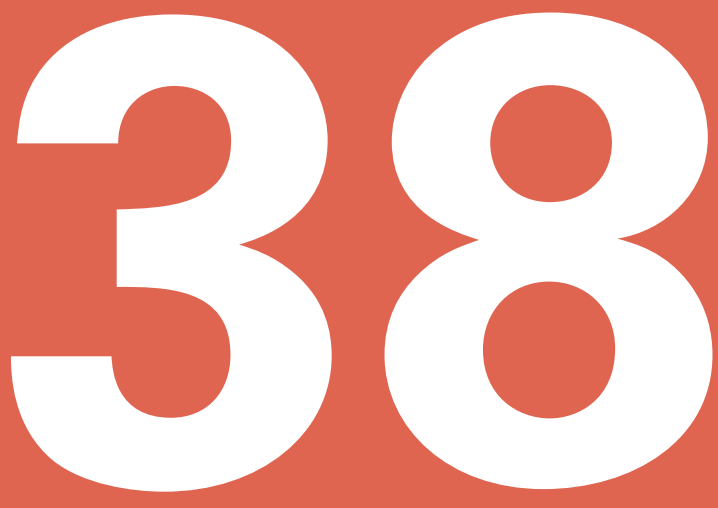

\section{Revista Portuguesa de História}

Faculdade de Letras da Universidade de Coimbra Instituto de História Económica e Social

Coimbra 08 
Revista Portuguesa de História

t. XXXVIII (2006)

pp. $135-153$

\section{O Estado Novo e a Guerra Civil de Espanha na sociedade das nações}

Fernando Rosas

FCSH - Universidade Nova de Lisboa

A 17 de Julho de 1936 inicia-se no Marrocos espanhol o pronunciamento militar das forças contrárias à República. No dia seguinte a rebelião estende-se à maioria das guarnições da Espanha. A revolta, porém, é derrotada em grande parte do território. Os insurgentes, liderados por Franco após o desastre mortal de Sanjurjo em Portugal ${ }^{1}$, assenhoreiam-se de uma larga faixa de território que vai da Galiza, a oeste, até à fronteira pirenaica. Mas, ao norte, as Astúrias (à excepção de uma bolsa em redor de Oviedo) e o País Basco mantêm-se sob controlo das forças republicanas, ou seja, toda a longa costa espanhola da baía da Biscaia. A sul, a frente rebelde não ultrapassa Cáceres e Segóvia, tendo uma infiltração mais profunda até Teruel. Em Aragão, a leste, pouco ia além de Saragoça e Huesca. O conjunto desta zona estava cortado das cidades andaluzes de Córdova e Sevilha, sitiadas pelos republicanos, e da bolsa de Cádis,

1 O general Sanjurjo, a quem se projectava atribuir a chefia da revolta e do novo Estado a instituir após o pronunciamento militar, vivia refugiado em Portugal, no Estoril. A 20 de Julho de 1937, o avião que o conduziria à zona rebelde para assumir o comando das operações despenhou-se ao procurar levantar da Quinta da Marinha, em Cascais (cf. Iva Delgado, Portugal e a Guerra Civil de Espanha..., pp. 34 e 35). 
que assegurava aos insurgentes o controlo do estreito de Gilbraltar e acesso a Marrocos. Por outro lado, a Armada permanecera no essencial fiel à República. Os objectivos do golpe militar tinham falhado, a guerra civil começava.

Numa Europa atravessando uma profunda convulsão política, o conflito em Espanha iria exacerbar drasticamente as contradições nacionais e internacionais, chamando as principais potências, sob a capa da «não intervenção», a tomar activa participação diplomática, política ou militar num confronto que todos a breve trecho pressentiram poder ser a antecâmara da Segunda Guerra Mundial. Conflito que passaria em larga escala à margem da Sociedade das Nações sem no entanto, deixar de se reflectir no seu seio com alguma relevância. O que faz da SDN e dos seus órgãos um útil posto de observação do conflito quando visto na perspectiva da evolução da sua dimensão internacional, a que para o caso sobretudo nos interessa.

\section{A posição das principais potências e do Governo português face à eclosão da Guerra Civil}

Nos dias imediatamente após o levantamento, Franco e os principais dirigentes rebeldes enviaram emissários a Mussolini e a Hitler para solicitar urgente apoio militar. Isolado a norte, quase sem portos de mar e sujeito a forte pressão, o grosso das forças insurgentes corria o risco de breve asfixia a menos que recebesse rápido auxílio aerotransportado. Mesmo as bolsas da Andaluzia precisavam de ser abastecidas sobretudo por via aérea, dado o cerco a que estavam sujeitas e o bloqueio marítimo exercido pela Armada republicana.

Para a Itália mussoliniana tratava-se de impedir a instalação de um «regime comunista» em Espanha e de obter o suporte de um Governo politicamente simpatizante em Madrid para apoiar os desígnios romanos de expansão mediterrânica. Beneficiando da activa interferência de Ciano, ministro dos Negócios Estrangeiros italiano, os franquistas asseguraram com relativa prontidão um vasto e diversificado apoio em material bélico (e depois em tropas legionárias) a partir de 25 de Julho de 1936, ou seja, uma semana após o pronunciamento: Ciano vai mesmo criar no seu ministério um Uffizio Spagna para coordenar o auxílio aos rebeldes.

Em Berlim, os delegados de Franco depararam com a resistência de Dieckhoff, então responsável pela diplomacia do Reich, que se opunha à intervenção alemã em Espanha, mas com o apoio incondicional do Partido Nazi e dos serviços secretos militares do almirante Canaris. Hitler, sem consultar o seu ministro dos Estrangeiros, resolve prestar uma ajuda sem reservas à revolta. Como mais tarde ele próprio afirmará, tratava-se menos de arranjar um seguidor ideológico do 
que visar objectivos estratégicos bem definidos: ameaçar a fronteira francesa dos Pirenéus; atravessar uma potência fascista nas comunicações marítimas anglo-francesas no Atlântico e no Mediterrâneo; cobiçar o minério de ferro espanhol, e alcançar a instalação de bases para os submarinos alemães nas costas de uma Espanha aliada. A 26 de Julho cria-se no Ministério da Guerra alemão uma secção com a designação $\operatorname{COS}$ «W» encarregada do recrutamento de «voluntários» para Espanha e do envio de material de guerra. Duas companhias comerciais constituídas para o efeito encarregar-se-iam da canalização e transporte das tropas e do material bélico sob escolta de navios da Armada alemã ${ }^{2}$

O Governo de Leon Blum, por seu turno, compreendera de imediato o perigo da vitória franquista para a França da Frente Popular. Mas, após uma atitude inicial de aquiescência ao pedido de ajuda militar da República espanhola, sob a crescente pressão de Londres, que ameaça desvincular-se dos compromissos de ajuda à França em caso de guerra, o gabinete de Paris cancela a exportação de material bélico para a Espanha e fecha a fronteira com esse país a 8 de Agosto. A ajuda francesa às forças republicanas continuaria a processar-se durante a vigência de governos de maioria socialista com episódicas aberturas de fronteira, mas principalmente através de terceiros países, especialmente do México.

Para a Grã-Bretanha, para o primeiro-ministro Baldwin e o secretário do Foreign Office, Éden, o conflito espanhol era sobretudo inoportuno. Éden diria que para o seu país, em termos de decisão da guerra, era inconveniente a vitória de qualquer dos lados. Mas a verificação do conflito em si mesma vinha prejudicar a negociação de um acordo de segurança colectiva na Europa, envolvendo a Grã-Bretanha, a França a Bélgica, a Alemanha e a Itália, que o gabinete britânico achava então possível celebrar, dado que, segundo cria, a remilitarização da Renânia e a anexação da Abissínia teriam acalmado os apetites territoriais de Berlim e Roma.

Nesse sentido a Grã-Bretanha desenvolve fortes pressões junto de Paris para suspender o auxílio à República, apadrinha activamente a proposta francesa de um acordo de não intervenção e orienta toda a sua acção na questão espanhola no sentido de impedir que ela interfira nessa política de apaziguamento dirigida à Alemanha e à Itália.

A URSS, entretanto, estava perante um dilema pouco fácil de resolver: por um lado, a vitória franquista, cercando a França pela «retaguarda», libertava as forças nazis para um eventual ataque à União Soviética. Esta teria, assim, o maior interesse em evitar o triunfo dos rebeldes. Por outro lado, a ajuda soviética à República não podia processar-se de molde a afastar os seus potenciais aliados

\footnotetext{
2 Cf. Hugh Thomas, A Guerra Civil de Espanha..., pp. 182 a 185.
} 
anglo-franceses, muito menos a inquietá-los com a perspectiva de uma guerra revolucionária «levada até ao fim», isto é, que se traduzisse por uma tomada de poder sob a hegemonia dos comunistas espanhóis. Nesse sentido se pode considerar que a URSS desejaria mais impedir a vitória dos franquistas do que intervir directamente para assegurar o triunfo da República ou da revolução em Espanha. Por isso, até meados de Outubro de 1936 se absterá de prestar qualquer apoio militar ao Governo de Valência, Colocará, no entanto, toda a máquina do Komintern, já afinada pela linha do frentismo antifascista, ao serviço do apoio à República em propaganda, fundos, matérias-primas, alimentos, etc., e destacará para Espanha vários quadros civis e militares do aparelho da Internacional Comunista. A própria ajuda directa soviética se restringirá inicialmente a um auxílio deste teor.

Já em Lisboa Salazar tinha menos dúvidas. O conflito que se travava em Espanha, segundo o Governo português, não era entre dois partidos mas entre duas «civilizações», e consequentemente não se podia ser neutro em tal disputa. Essa vai ser a orientação transmitida mesmo para a acção diplomática logo após o eclodir da guerra ${ }^{3}$. O regime português tinha a clara noção de que, em certa medida, era a sua sorete que se decidia na Guerra Civil. Lisboa e o Estoril, refúgio e sede de conspiração anti-republicana até à insurreição, tornaram-se no quartel-general centralizador da ajuda internacional ao franquismo. Mesmo antes de cortar relações com o Governo da República, Salazar dá inteira liberdade de movimentos a uma «embaixada negra» dos rebeldes funcionando na capital, e assegura o apoio financeiro e cobertura legal a todo o tipo de operações comerciais portuguesas e estrangeiras de apoio aos franquistas, em armas e abastecimentos variados.

No período crucial em que as forças revoltosas se encontravam separadas, o Governo português assegura a ligação entre elas, designadamente pelo Rádio Clube Português, e canaliza, através do Porto de Lisboa e do território nacional, para a zona franquista a ajuda militar alemã. Especialmente os aviões desmontados, com que foi possível dotar os rebeldes de aviação e reforça-los em homens e material vindos do Norte de África para poderem resistir e depois progredir para norte e atacar em Badajoz, unindo o Norte aos núcleos insurrectos do Sul. Alguma razão tinha a imprensa republicana espanhola ao afirmar que «sem Portugal já estaria vencida a sublevação dos militares espanhóis há muito tempo» ${ }^{4}$.

\footnotetext{
${ }^{3}$ Cf. Franco Nogueira, Salazar, vol. III..., pp. 13 a 15.

4 Iva Delgado, Portugal..., pp. 37 e 38.
} 
Mas para o regime de Burgos, e para uma Alemanha e Itália que a Guerra Civil de Espanha vai fazer aliadas, o Governo de Lisboa será sobretudo o peão avançado da não menos intensa e importante batalha diplomática que rodeia o conflito: enquanto as resistências e dilações portuguesas permitem demorar ou torpedear qualquer acordo internacional, os dois parceiros principais de Franco, formalmente mais cordatos, têm tempo de armar e reforçar maciçamente os rebeldes por forma a esvaziar de conteúdo qualquer compromisso de não intervenção. Essa a regra geral do comportamento diplomático português ao longo de todo o conflito, logo a partir de Agosto de 1936.

\section{O acordo de não intervenção de Agosto de 1936: a questão espanhola fora da SDN}

O acordo de não intervenção é proposto a 2 de Agosto de 1936 pelo Governo francês e imediatamente apoiado e promovido por Londres. Após algumas reservas iniciais, a Alemanha, a Itália e a URSS declaram a sua intenção de aderir. O Governo dos EUA manifestou a sua adesão à não intervenção em 5 de Agosto. Só em Lisboa se resiste e adia, apesar das diligências britânicas. Qualquer acordo similar podia, na altura, prejudicar o apoio à ofensiva franquista em curso sobre Badajoz. A 14 de Agosto a cidade cai, permitindo nos dias imediatos a junção norte-sul das tropas de Franco, a incorporação na frente dos revoltosos das bolsas de Córdova, Sevilha e Cádis e o ataque a Granada. Simultaneamente, a norte, os franquistas ocupam Irum, retomando o contacto com a fronteira pirenaica e cercando definitivamente as zonas republicanas do País Basco e das Astúrias.

A 21 de Agosto, o governo português presta finalmente a sua adesão de princípio à não intervenção, mesmo assim declarando unilateralmente várias reservas que praticamente esvaziam de significado a aceitação do acordo. A 9 de Setembro começa a funcionar em Londres, no Foreign Office, uma Comissão da Não Intervenção composta pelos delegados dos seis países mais directamente envolvidos ou interessados no conflito espanhol: a Alemanha, a Itália, a França, a Grã-Bretanha, a URSS e Portugal.

Após as derrotas militares que acabava de sofrer, a não intervenção constituía um golpe de não menos importância para o Governo da República, indo as suas consequências pesar decisivamente nos destinos da guerra civil. Aliás, o Governo de Madrid opusera-se afincadamente à concretização de um tal acordo e nunca deixará, ao longo do conflito, de procurar derrogá-lo. Até certo ponto, esse vai ser o eixo da diplomacia republicana junto dos organismos da Sociedade das Nações até 1938. 
Não é difícil compreender porquê.

Em primeiro lugar os republicanos eram de opinião que a Guerra Civil não podia ser encarada exclusivamente como um assunto interno da Espanha. O Governo legítimo da República, saído das eleições de 16 de Fevereiro de 1936, estaria a ser vítima de uma agressão internacional materializada na intervenção militar da Alemanha e da Itália, tendo como instrumento os rebeldes que «pegavam em armas contra a legitimidade constitucional republicana». «A luta já se teria resolvido se (...) o povo espanhol», além da acção dos revoltosos, «não se visse obrigado a fazer frente a uma outra agressão muito mais vasta e extensa», expressa pela «entrada em acção de um imenso material de guerra estrangeiro que os rebeldes não possuíam no momento do levantamento». Nesse sentido o Governo republicano, alvo de uma agressão estrangeira, não lutaria «somente pela segurança e paz interna da Espanha, mas também pela segurança dos outros povos e pela paz mundial». Ou seja, a questão espanhola caía sob a alçada do Pacto da SDN, cujos mecanismos de segurança colectiva deviam ser accionados em apoio ao Governo legal: «Um sistema de segurança colectiva previsto para devolver a confiança aos povos deva antes do mais proteger os Estados contra os riscos de movimentos internacionais apoiados e fomentados do exterior». Ajuda que a Espanha teria tanto mais direito de esperar quanto a Constituição republicana incorporara no seu texto o Pacto da SDN 5 .

Mas mesmo quando assim se não entendesse, o Governo de Valência aceitaria, pelo menos, «uma política rigorosa de não intervenção» que ignorasse completamente a situação interna em Espanha, mantendo em vigor as relações e os acordos comerciais anteriores - nomeadamente no tocante à compra de armas pelo Governo legal - e se abstivesse de interferir apoiando e armando os rebeldes. Para isso, para respeitar o que deveria ser a situação normalmente decorrente das «mais elementares obrigações internacionais», não era necessário nenhum acordo de não intervenção: esse seria o dever mínimo de todos os países que mantinham relações diplomáticas com o Governo espanhol.

No entanto, não fora isso que se passara. Segundo os republicanos, o acordo de não intervenção, ao proibir a todos os países que o tinham subscrito a exportação de material de guerra para qualquer das partes em conflito na guerra civil, punha «em pé de igualdade o governo legítimo e os rebeldes», impedindo aquele de se defender como era seu direito. Nesse sentido o denunciavam como uma «monstruosidade jurídica», uma «inovação nas regras do direito internacional, na medida em que representa a recusa de meios de acção a um

5 Alvarez del Vayo. Compte rendu de la $17^{\text {eme }}$ séssion ordinaire de l'Assemblée de le Société dês Nations, $\sigma^{\text {éme }}$ s.pl., 25-9-1936. 
governo legítimo». Além do mais, a cessação brusca de exportação de material de guerra para Espanha só afectaria verdadeiramente o Governo legal, posto que os rebeldes tinham continuado a ser abundantemente fornecidos mesmo após o acordo, o que levava os republicanos a considerarem que «o que se chama política de não intervenção é a política de intervenção em prejuízo do governo constitucional e responsável... é uma intervenção efectiva, directa e positiva em favor dos rebeldes» ${ }^{6}$.

Nesse sentido se pronunciaria Alvarez del Vayo ao discursar a 25 de Abril de 1936 na $17^{a}$ sessão ordinária da Assembleia da SDN, numa intervenção que se tornaria célebre como expressão do drama e da impotência da República espanhola, encurralada entre os arranjos das principais potências. Nela o ministro dos Negócios Estrangeiros do Governo de Madrid previa que «os campos ensanguentados de Espanha são já, na realidade, os campos de batalha da guerra mundial». Mas os Governos europeus pareciam não levar isto muito a sério.

A Assembleia desse ano não prestou grande atenção ao caso espanhol, colocado fora do âmbito da SDN pelo acordo de não intervenção. Nenhum dos delegados das principais potências europeias se referiu sequer a ele, e mesmo o representante da URSS não o aflorou senão de passagem, para justificar a adesão soviética ao acordo. Segundo Litvinoff, o seu Governo só o subscrevera dadas as apreensões da França - com quem tinha um tratado de aliança e amizade -, posto que não achava que se pudesse ser neutral num conflito que opunha um governo legítimo e uma revolta interna, classificando mesmo o acordo como uma «decisão injusta». Desejoso, por um lado, de agradar aos franceses e ingleses no cumprimento da estratégia de defesa da URSS, Estaline pretendia, por outro, não dar a sensação de que abandonava a revolução mundial, como deixavam entender as queixas amargas do Governo espanhol e o afirmavam claramente as críticas dos partidos de orientação trotsquista dentro e fora de Espanha.

O único Governo do mundo que desafiou expressamente o acordo de não intervenção para apoiar a República espanhola foi o do México. E isso mesmo declarou na Assembleia de 1936 o delegado mexicano ao criticar «a solução injusta que consiste em privar dos meios de legítima defesa um governo que se vê subitamente combatido no seu próprio solo por forças que se opõem, de armas na mão, ao desenvolvimento normal das aspirações populares, tudo para evitar hipotéticas complicações de ordem internacional». Considerando o acordo de não intervenção como «uma verdadeira regressão, um passo atrás» no direito internacional, o Governo do México informava ter «definido desde

\footnotetext{
6 Ibidem.
} 
o princípio do conflito a sua política de cooperação material com o Governo legítimo de Espanha, que enfrentava um levantamento militar?

Só mais uma delegação se referiu nessa Assembleia à situação em Espanha: a do Governo português. E de forma bastante significativa. Na ausência de representação da Junta de Burgos e dos seus aliados alemães e italianos na Sociedade, cabia ao Governo de Lisboa esgrimir com os argumentos do delegado da República. Disso se encarregou, com prudência mas de forma clara, Armindo Monteiro, então ainda ministro dos Negócios Estrangeiros, na sessão plenária da Assembleia de 30 de Setembro. Depois de «prestar homenagem à política de não intervenção... que não tinha talvez em conta o plano particular em que se desenrolavam as ansiedades portuguesas, mas [que] é profundamente europeia», e de informar a adesão prestada pelo seu Governo ao respectivo acordo - «salvaguardando mediante algumas reservas as circunstâncias especiais em que se encontra»-, Armindo Monteiro, ainda que falando em abstracto, passou a questionar um dos principais fundamentos da intervenção de del Vayo: o da legitimidade do Governo republicano. «Suponhamos», afirmou, «que a maioria de um povo e tudo o que ele tem de verdadeiramente representativo: a tradição, a cultura e a força, a vontade de ordem e de justiça, o desejo de unidade e de grandeza, os quadros do trabalho e dos serviços públicos, a riqueza, enfim, se levanta contra um governo. Poder-se-á continuar a considerá-lo como legítimo?» Para obviar a esta dificuldade é que se impunha uma «oportuna política de não intervenção. Sem ela poder-se-ia facilmente correr o risco de, por respeito a uma ficção jurídica, socorrer um governo que, divorciado da vontade nacional, tivesse perdido toda a legitimidade e mesmo toda a autoridade». E concluía: «Em certo momento, a legitimidade pode não ser senão a vã aparência de uma inexistente conformidade com o direito» ${ }^{8}$.

Naturalmente, a delegação espanhola dificilmente deixaria sem comentário a intervenção de Armindo Monteiro, dado o perigoso precedente que ela deixava adivinhar de legitimação da revolta franquista e do apoio externo a ela. Ossorio y Gallardo, três dias depois, usava da palavra para afirmar, em resposta ao delegado português, que «compreendemos bem de mais que certas teses sejam aqui apresentadas com intuitos puramente científicos e sem a menor intenção de as aplicar às realidades concretas, e menos ainda à situação da Espanha». Mas para não se pensar que, calando-se, a delegação espanhola concordava com elas, Gallardo precisava que «se a liberdade e a personalidade das nações estivesse sujeita à livre apreciação da nossa Sociedade ou à apreciação

\footnotetext{
7 Narciso Bassols (delegado do México), idem, 13 ${ }^{\text {ème }}$ s. pl., 2-10-1936.

8 Armindo Monteiro, idem, $11^{\text {ème }}$ s. pl., 30-9-1936.
} 
interessada de um outro povo, não existiria nenhum país que pudesse ser senhor de si próprio». E rechaçava a teoria segundo a qual «um Estado pode ser mais ou menos respeitável segundo os inimigos que conspiram contra ele. Extrair argumentos de facto de certos elementos da riqueza, da força, da cultura tomarem posição contra um governo seria colocar o problema em termos de uma anfibiologia inaceitável». Para Gallardo «nenhum dos Estados aqui representados toleraria certamente que fosse um terceiro a definir a sua soberania... o poder legítimo de um povo é aquele que é escolhido de acordo com as normas jurídicas desse povo...A República existe porque o povo pacificamente a instituiu». E, em jeito de aviso ao regime português, concluía: «A teoria contrária apresentaria perigos que podem atingir os povos que pensam menos dever temê-los, pois pode acontecer que noutros países se levantem forças contra o governo e façam tudo o que esteja ao seu alcance para o derrubar. Será que os governos atacados admitiriam que nós tomássemos a iniciativa de julgar as duas partes em causa?» ${ }^{9}$

Este despique isolado não alterou, no entanto, a atitude fundamental da SDN de não querer chamar a si a questão espanhola. O próprio Governo da República, apesar do seu protesto e divergência, não apresentou então qualquer proposta nesse sentido.

Todo o final do ano de 1936 decorre sob o signo do completo malogro da não intervenção. Enquanto a Alemanha, a Itália e Portugal vão protelando a aceitação de um plano de controlo da não intervenção reforçando (as duas primeiras) com tropas regulares e material de guerra o exército franquista, as propostas anglo-francesas de mediação e de interdição da ida de voluntários para Espanha chocam com a oposição de ambas as partes do conflito. Em 15 de Outubro, sob pressão dos quadros do PC espanhol e do Komintern, a URSS começa a enviar armas, tanques e aviões para Espanha. Os primeiros contingentes das Brigadas Internacionais, por seu turno, chegam a Barcelona em meados desse mês e vão defender Madrid. Em fins de Novembro, o Governo da vão defender Madrid. Em fins de Novembro, o Governo da República retira para Valência.

Face a tal situação, em 10 de Dezembro, del Vayo, contrariando a opinião de Litvinoff, apresenta pela primeira vez a questão espanhola ao Conselho da SDN: pede a condenação da Alemanha e da Itália como agressores e o reconhecimento da ineficácia da não intervenção, no sentido de a República poder retomar a plena liberdade de movimentos para se defender. Mas o Conselho, instigado pela Grã-Bretanha e pela França, limita-se a adoptar uma resolução condenando

\footnotetext{
9 Ossorio y Gallardo (delegado em Espanha), idem, 14 ${ }^{\mathrm{eme}}$ s. pl., 2-10-1036.
} 
a intervenção, e pedindo aos Estados do Comité de Londres que respeitassem o acordo e recomendando a mediação, prontamente recusada pelos dois lados.

\section{Iniciativas do Governo da República espanhola perante o Conselho e a Assembleia da SDN em 1937}

\section{O desenvolvimento da Guerra Civil e da «não intervenção»}

Só a 16 de Fevereiro de 1937, após Goering, Ciano e Mussolini se terem assegurado, num encontro realizado em Roma no início do ano, que a «Espanha estava bem fornecida ${ }^{10}$, e o Governo português ter finalmente aceite o princípio da fiscalização dos seus portos e fronteiras terrestres ${ }^{11}$, foi possível aprovar no Comité de Londres o plano de controlo da não intervenção proposto em Novembro do ano anterior pelo delegado britânico, Lord Plymouth. Claro que o paralelismo entre os sucessos diplomáticos do Comité e as ofensivas franquistas se voltava a repetir: a 8 de Março os legionários fascistas italianos (parte deles já enviados após o acordo de 16 de Fevereiro) atacam em Guadalajara tentando cercar Madrid, onde sofrem, aliás, uma grave e embaraçosa derrota para as armas e a diplomacia de Roma. E a 31 de Março Mola lança, com cobertura aérea da Divisão Condor alemã e da força aérea expedicionária italiana, a ofensiva geral contra o País Basco.

A 28 de Maio, face ao desmoronamento da frente basca e à completa ineficácia da não intervenção e respectivo controlo, Alvarez del Vayo apresenta novamente queixa no Conselho da SDN contra a Alemanha e a Itália, contestando a «farsa da não intervenção». Mais uma vez a Grã-Bretanha e a França estão atentas para que não se tomem resoluções que irritem os Governos alemão e italiano ou lhes dêem pretexto para abandonar o Comité de Londres. O Conselho limita-se a adoptar uma resolução que condena o bombardeamento de cidades abertas (Guernica fora a 26 de Abril) sem especificar os seus autores, lamenta o não cumprimento da sua resolução de Dezembro, pede a retirada dos voluntários, e na qual, suprema ironia, se regozija com a entrada em vigor da fiscalização da não intervenção.

${ }^{10}$ Hugh Thomas, A Guerra..., p. 276.

${ }^{11}$ Só em Fevereiro de 1932, e após claras ameaças britânicas de bloqueio naval às costas portuguesas, Salazar se decide a permitir a fiscalização dos portos e fronteiras terrestres portuguesas, e mesmo assim unicamente a título de facilidades especialmente concedidas a observadores britânicos, como representantes do Governo de Londres. 
Apesar de tudo, um primeiro resultado começa a aflorar da persistência da diplomacia republicana: a progressiva deslocação da questão espanhola para a SDN face à paralisia do Comité de Londres. E essa tendência mais se iria acentuar, e até com algum êxito, na $18^{\mathrm{a}}$ sessão plenária da Assembleia da Sociedade iniciada em Genebra a 13 de Setembro desse ano.

No entanto, a República chegará lá numa situação política e militar bem mais grave do que um ano antes. Por várias razões:

- No plano militar, Bilbau e o País Basco tinham caído a 18 de Junho, e Santander, nas Astúrias, em 22 de Agosto. A 1 de Setembro iniciara-se o ataque franquista a Gijon, último reduto republicano nas Astúrias e no Norte de Espanha. A contra-ofensiva republicana em Aragão, lançada a 24 de Agosto, caíra entretanto no impasse. As posições no Norte pouco mais poderiam aguentar, apesar da desesperada defesa de bascos e asturianos em torno daquele porto de Biscaia;

- Em fins de Junho, a Itália e a Alemanha abandonam definitivamente o patrulhamento naval e o esquema de fiscalização ${ }^{12}$. Portugal suspende de imediato as facilidades aos observadores britânicos para controlo dos portos e fronteiras terrestres. Em Julho, a não intervenção fora virtualmente abandonada. No mês seguinte inicia-se a campanha dos submarinos italianos contra todos os navios mercantes com destino aos portos republicanos;

- Com a agressão japonesa à China, desencadeada em Julho, parte do auxílio militar soviético é desviado para os exércitos chineses, e o que vem para Espanha, quase todo por via marítima dado o encerramento da fronteira francesa, depara com grandes dificuldades para furar o bloqueio naval dos franquistas e dos submarinos «fantasma» de Mussolini;

- Desde Maio que N. Chamberlain é o novo primeiro-ministro britânico, agravando a política de contemporização da diplomacia britânica para com a Alemanha e a Itália e de marginalização da questão espanhola. Também a 28 desse mês o Vaticano, após Hitler e Mussolini, reconheça oficialmente o Governo de Burgos.

${ }^{12}$ A Alemanha e a Itália tinham abandonado o Comité de Londres em 31 de Maio de 1937 após o ataque da aviação republicana ao navio de guerra alemão Deutschland (que se encontrava irregularmente em Ibiza). Os alemães retaliaram, bombardeando dois dias depois Almeria com s aua marinha de guerra e desligando-se da não intervenção. Em Junho regressam ao comité sob pressão franco-britânica, para no dia 26 desse mês se desligarem definitivamente ao patrulhamento naval (mas já não do Comité de Londres) na sequência de novo incidente com o navio alemão Leipzig. 
Entretanto, e quase em simultâneo com a abertura da Assembleia da SDN, registava-se com a Conferência de Nyon um assomo da segurança colectiva: face aos excessos dos ataques dos submarinos «fantasmas» italianos contra navios de várias nacionalidades (incluindo britânicos) e a indignação da opinião pública, a Grã-Bretanha vira-se forçada a organizar, juntamente com a França, a União Soviética e os países mediterrânicos, um esquema de patrulhamento naval e de resposta militar no Mediterrâneo. Mas toda a iniciativa correra fora da SDN e, principalmente, o Governo de Valência, primeira vítima das incursões submarinas, fora afastado do acordo. Em contrapartida, a Itália, que juntamente com a Alemanha se recusara inicialmente a participar na Conferência, é associada às suas decisões pouco depois.

\section{O debate na $18^{a}$ sessão da Assembleia da SDN}

Em Setembro de 1937 a Assembleia da SDN vai pela primeira vez discutir a questão espanhola com alguma profundidade. Nesse ano a Espanha presidira ao Conselho da SDN e é o primeiro-ministro da República, Negrín, que pronuncia o discurso de abertura dos trabalhos dessa sessão da Assembleia e chefia a delegação espanhola.

Já o relatório do secretário-geral desse ano abordara, ainda que em termos muito cuidadosos, a situação em Espanha. E o delegado norueguês, exprimindo um pouco o sentir de vários pequenos e médios Estados europeus, perguntava se seria digno «a Sociedade das Nações guardar um completo silêncio face à luta civil que dividia a Espanha há catorze meses», fazendo um apelo à mediação da Sociedade ${ }^{13}$.

De facto os bombardeamentos das cidades, as acções dos submarinos italianos contra navios mercantes indefesos, o ataque alemão a Almeria, o prolongamento dos horrores da guerra, a falência da não intervenção, tudo isso criava um ambiente internacional favorável a que a SDN considerasse com outra atenção a questão de Espanha. E o discurso de Negrín na Assembleia, a 18 de Setembro, vai procurar capitalizar em favor dos objectivos já conhecidos da diplomacia republicana esse novo estado de espírito. Articulou-se a alocução do primeiro - ministro da República na base dos seguintes 5 pontos integrantes da proposta que então apresenta à Assembleia.

${ }^{13}$ Halvdan Koht (delegado da Noruega), Compte rendu de la $18^{\text {eme }}$ séssion ordinaire..., $5^{\text {ème }}$ s. pl., 18-9-1937. 
$1^{\circ}$ ) Explicitação da agressão estrangeira de que a República era vítima por parte da Alemanha e da Itália, pedindo o seu reconhecimento e a sua condenação expressa pela SDN. «Sem intervenção estrangeira», dizia, «a rebelião teria sido liquidada em algumas semanas... Perante a incapacidade dos rebeldes vencerem desde logo a resistência republicana, com que ninguém contava, a Alemanha e a Itália passaram de um apoio político à rebelião a um auxílio armado». E não esquece o Governo de Lisboa: «Não tendo outra ajuda a fornecer, Portugal ofereceu generosamente, desde o começo, a ilimitada colaboração dos seus portos e das suas fronteiras para reduzir, na medida do possível, as dificuldades de transporte». Nestes termos, após indicar factos em abono dessas afirmações, concluía Negrín que «a guerra de invasão relegou para segundo plano a guerra civil... a amizade da Alemanha e da Itália com os rebeldes não é senão o resultado de um pacto de ocupação» e «o conflito espanhol passou a assumir um carácter internacional dada a intervenção estrangeira»;

$2^{\circ}$ ) Que face ao reconhecimento do ponto anterior «a Sociedade das Nações examine urgentemente a forma de pôr termo a esta agressão». A Espanha era membro da SDN, consequentemente «é à Sociedade que cabe exigir a cada um a explicação das obrigações resultantes do Pacto»;

$3^{\circ}$ ) «A integral devolução ao Governo espanhol do seu direito de adquirir livremente todo o material de guerra que considere necessário». Era a proposta de derrogação do acordo de não intervenção, cujos efeitos Negrín ataca com a maior severidade por «agravarem a intervenção já consumada pela Itália e a Alemanha com uma forma de intervenção consistente em atar de pés e mãos o Governo espanhol, impedindo-o de obter livremente os meios de guerra necessários para reduzir e vencer a rebelião». Facto que «em nada tinha impedido a não intervenção de ser uma amarga ficção, nem diminuído a ameaça de extensão de guerra». E ainda que reconhecendo as boas intenções «dos seus nobres promotores», Negrín declarava que «a não intervenção está morta, bem morta, mas o seu cadáver insepulto corrompe a atmosfera dos meios internacionais». Havia, pois, que a enterrar;

$4^{\circ}$ ) A retirada do território espanhol dos «combatentes não espanhóis», e não "voluntários"...voluntários são só os que lutam nas nossas fileiras... Face a eles, as divisões italianas, os artilheiros, aviadores e condutores dos tanques alemães, os contingentes mouros»;

$5^{\circ}$ ) A extensão das medidas de segurança adoptadas na Conferência de Nyon à Espanha, cuja participação no acordo devia ser assegurada por direito próprio ${ }^{14}$.

\footnotetext{
${ }^{14}$ Juan Negrín, idem, ib.
} 
Só duas delegações intervêm no debate para defender explicitamente as propostas de Negrín: as do México e da União Soviética. Litvinoff, desta feita, critica asperamente a política de não intervenção, exigindo a aplicação do Pacto à questão espanhola e avisando que o Governo soviético se reserva o direito de não cumprir o acordo se verificasse que nele era «o enganado». Mas regozija-se com os resultados da Conferência de Nyon, vendo nela as virtualidades da aplicação dos esquemas de segurança colectiva.

A Grã-Bretanha e a França, por seu turno, vêm à liça para defender a manutenção da política de não intervenção. Éden, ainda à cabeça do Foreign Office, declara que graças a ela «se impediu um conflito europeu» e que, apesar de algumas violações, «o objectivo principal que visava essa política foi até agora atingido». E concluía: «Se renunciar-mos a ela a Europa ver-se-á precipitada numa via ainda mais perigosa. Um dique, mesmo com brechas, continua a servir os fins para que foi construído» ${ }^{15}$.

Portugal, numa atitude de grande discrição face às actividades da Assembleia, quiçá a deixar adivinhar o momento particularmente tenso das relações do Governo de Lisboa com Londres e Paris, vai tomar a palavra unicamente para se pronunciar sobre a questão espanhola. A 20 de Setembro, Caeiro da Mata, delgado do Governo português, responde às acusações de Negrín, que classifica de «alusão à atitude hostil de Portugal face a uma pequena fracção da grande e infeliz terra de Espanha». Depois de lembrar que o Governo português, apesar de ter rompido relações diplomáticas com o Governo de Valência, não reconhecera «o Governo do general Franco», Caeiro da Mata reafirma enfaticamente a «neutralidade absoluta face aos dois Governos» e garante que «Portugal nunca foi, desde o início da Guerra Civil, um país de trânsito de material de guerra estrangeiro».

Mas, numa posição de desafio absolutamente singular em toda a Assembleia, não deixa dúvidas sobre o lado que Lisboa apoiava: «É certo que desejamos de todo o coração - e hoje mais do que nunca - o triunfo do nacionalismo espanhol, e isso pela simples razão de que todos sabemos que a absorção de Portugal pela Espanha é uma das aspirações do comunismo ibérico». E «comunismo ibérico quer dizer mais ou menos Governo de Valência»» ${ }^{16}$.

Realizado o debate do relatório do secretário-geral, a Assembleia concordou em remeter a proposta de Negrín para apreciação da sua $6^{\mathrm{a}}$ Comissão. Nela iria prosseguir a discussão, de forma, aliás, particularmente viva.

\footnotetext{
${ }^{15}$ A. Éden, idem, $6^{\text {ème }}$ s. pl.,20-9-1937.

${ }^{16}$ Caeiro da Mata, idem, $7^{\mathrm{ème}}$ s. pl., 20-9-1937.
} 


\section{A proposta da $6^{a}$ Comissão}

A $6^{\text {a }}$ Comissão da Assembleia chegou a um consenso substancialmente favorável às pretensões dos representantes da República espanhola, o que originou, aliás, uma sua aceitação reticente e contrariada por parte da Grã-Bretanha. Mas, salvo algumas cedências com certa importância, os objectivos principais da Espanha viam-se consagrados na proposta de resolução adoptada.

Após apelar para o respeito da integridade territorial do Estado espanhol, e de lembrar o dever de não intervenção nos seus assunto internos por parte de todos os países, bem como os objectivos do Comité de Londres, o ponto $4^{\circ}$ da proposta lamenta que o referido Comité «não tenha conseguido assegurar a retirada dos combatentes não espanhóis participantes na luta em Espanha», reconhecendo «a existência em território espanhol de verdadeiros corpos de exército estrangeiros, o que representa uma intervenção estrangeira nos assuntos de Espanha» (sublinhados nossos).

Seguidamente recomendava-se a «retirada imediata» desses combatentes e estabelecia-se no seu ponto $7^{\circ}$ que «se tal resultado não fosse obtido a curto prazo, os membros da Sociedade que aderiram ao acordo de não intervenção encararão o fim da política de não intervenção» ${ }^{17}$. $\mathrm{O}$ «curto prazo» fora a única cedência feita pela Espanha, que lutara por impor um limite temporário preciso para liquidar a política de não intervenção. Quanto ao resto reconhecia-se a «intervenção estrangeira nos assuntos de Espanha» utilizando os termos empregues pela própria delegação espanhola («combatentes não espanhóis») e identificando os interventores por forma a contemplar especificamente as forças regulares ítalo-alemãs, as únicas tropas estrangeiras combatentes em Espanha («corpos de exército estrangeiros»).

\section{A votação na Assembleia}

$\mathrm{Na} 11^{\mathrm{a}}$ sessão plenária da Assembleia, realizada a 2 de Outubro, discutiu-se e votou-se finalmente a resolução submetida pela $6^{\mathrm{a}}$ Comissão.

Desde logo se afirmou um núcleo abstencionista com dois tipos de argumentos:

a) Estados como a Irlanda, a Argentina, a Bolívia, o Uruguai, a Venezuela e o Chile declaram a sua intenção de se absterem por temer que a resolução acarretasse, por força do seu número $7^{\circ}$., o fim da política de não intervenção e de neutralidade face à Guerra Civil;

${ }^{17}$ «Situation en Espagne et questions connexes» (proposta de resolução apresentada pela $6^{\mathrm{a}}$ Comissão) idem, 11 ${ }^{\text {ème }}$ s.pl.,2-10-1937. 
b) A Áustria, a Hungria e a África do Sul opunham-se, por seu turno, à «constatação não suficientemente detalhada» da intervenção estrangeira feita no ponto $4^{\circ}$., considerando-a «unilateral». Adiantaram por isso várias propostas de alteração.

AAlbânia e Portugal subscreviam essas objecções, especialmente a segunda, mas declaravam a sua intenção de votar contra a proposta. Caeiro da Mata produz na altura uma pormenorizada intervenção, apontando o que entendia ser a parcialidade com que se caracterizava a intervenção estrangeira, discorrendo sobre a diferença entre «corpos de exércitos estrangeiros» e «corpos de exército com estrangeiros» (por exemplo legionários), e declarando que a questão essencial, mesmo na eventualidade de se encontrarem em Espanha tais «corpos de exército estrangeiros», era a de saber qual a ordem de prioridade das intervenções, uma vez que não se poderia falar de «uma intervenção», mas sim de várias.

Em favor da proposta e contra as emendas adiantadas pela Áustria e a Hungria pronunciaram-se a Polónia (posição sintomática: o Estado polaco, insuspeito de simpatias pelos rojos, estava já a braços com a tempestade de Dantzig), a Colômbia, o Equador e o México (o núcleo de membros latino-americanos apoiantes das posições do «bloco da paz» e da República), a URSS, a Espanha (que publicamente expressa a sua contrariedade com o carácter vago de «curto prazo» previsto no ponto $7^{\circ}$ ) e finalmente a França e a Grã-Bretanha, para quem a proposta já contemplaria, afinal, as preocupações dos proponentes das emendas...

Recusadas as alterações desejadas pela Áustria e Hungria, a votação final e global produziu os seguintes resultados: 32 votos a favor da proposta, 14 abstenções e 2 votos contra (a Albânia e Portugal). A proposta seria, assim rejeitada por falta de unanimidade. A República averbava talvez, apesar de tudo, uma vitória moral, mas os seus efeitos pouco se fariam sentir na evolução da guerra civil.

\section{O progressivo apagamento da questão espanhola na SDN}

\section{A viragem de fins de 1937}

O final de 1937 marca o ponto de viragem definitivo das operações militares em Espanha a favor dos franquistas. Com a queda de Gijon, a 21 de Outubro, Franco vai poder deslocar para o Sul 65000 homens, uma vez dominadas as últimas bolsas de resistência nas montanhas leonesas. A República perdera com o Norte toda a costa, e com ela os portos de Biscaia, bem como as preciosas 
minas de ferro asturianas e os importantes centros industriais e siderúrgicos do País Basco. Era precisamente em tais zonas que se concentravam boa parte dos interesses económicos britânicos. Por isso, o revês militar vai ter uma grave consequência política: em 16 de Novembro, o Governo britânico designa um agente diplomático junto do Governo de Burgos. No mês seguinte, para lá partirá também Teotónio Pereira, com idêntico estatuto, para representar o Governo português. A ofensiva republicana em Teruel, desencadeada em Dezembro, poucos efeitos produzira nas posições da frente de batalha após alguns êxitos iniciais. À República começam a pôr-se problemas sérios de abastecimentos e municiamento em material de guerra, com a fronteira francesa só intermitentemente aberta, um cerrado bloqueio naval e a progressiva diminuição da ajuda soviética.

\section{A evolução da Guerra Civil na nova conjuntura internacional}

Em 1938 os acontecimentos político-militares precipitam-se:

- Os franquistas desencadeiam em Janeiro uma contra-ofensiva em Teruel, e a 15 de Abril atingem o Mediterrâneo, dividindo em dois o território da República. Em Março, Yague atacara em Aragão, aproximando-se da Catalunha. A esperançosa ofensiva republicana no Ebro, em Julho, viria a estagnar e a revelar-se um sorvedouro fatal de homens e material para a resistência de Barcelona e da República;

- No plano diplomático a situação não era melhor: em Fevereiro, A. Éden é substituído por Lord Hallifax na direcção de Foreign Office, agravando-se substancialmente a política de apaziguamento com a Alemanha e a Itália. Fruto dela é o pacto ítalo-britânico de 16 de Abril, mediante o qual, implicitamente, e não obstante o acordo de não intervenção tão caro aos ingleses, a Grã-Bretanha reconhecia a Mussolini o direito de manter tropas em Espanha (eram as Baleares que sobretudo preocupavam Londres) até ao termo da Guerra Civil;

- Mas principalmente, em Setembro, dava-se o desfecho da crise dos Sudetas com o Acordo de Munique entre a Grã- Bretanha, a França, a Alemanha e a Itália: era o golpe de morte da diplomacia das grandes potências contra a segurança colectiva da SDN, novamente à custa dos países mais fracos, neste caso da Checoslováquia; era o isolamento internacional da URSS, e era ainda, por maioria da razão, o dobre a finados para qualquer esperança de intervenção da comunidade internacional contra a ingerência ítalo-alemã na Espanha. Para esta, com uma consequência adicional: a União Soviética intensifica o seu próprio armamento face à nova conjuntura - cortando substancialmente os abastecimentos militares à República 
nesta fase desesperada da sua resistência - e, falida a política de alianças a ocidente, vira-se decididamente para a busca de uma paz separada com Hitler. Tudo, em suma, se voltava contra o Governo de Negrín, agora instalado em Barcelona e remetido à defensiva nos territórios catalães e nas zonas - ainda significativas - em redor de Madrid e de Valência;

- Em Maio, Alvarez del Vayo insiste no Conselho da SDN na necessidade de rever a política de não intervenção, invocando a proposta apresentada em Outubro na Assembleia. Mas, apesar de ter aumentado o número de abstenções de simpatia (nove Estados), a Grã-Bretanha, a França e a Roménia inviabilizam a pretensão espanhola, que só conta com o voto da URSS. O Comité de Londres, por seu turno, deixa de reunir a partir de Julho.

Entretanto, desde fins de 1937 Negrín inicia diligências várias para obter uma paz negociada com os franquistas. Essa parece ser, aliás, a preocupação dominante na intervenção da delegação espanhola durante a $19^{\mathrm{a}}$ sessão plenária na Assembleia da SDN, que reúne pela última vez em Genebra a partir de 12 de Setembro de 1938.

\section{As propostas de Negrín na $19^{a}$ sessão ordinária da Assembleia}

Em Setembro e Outubro de 1938, decorrendo em simultâneo com as conversações diplomáticas que conduziram ao Acordo de Munique (assinado no dia em que a Assembleia suspende os seus trabalhos), a 19a sessão plenária tem já as suas preocupações dominantes longe da Espanha. A Guerra Civil retoma o estatuto de questão nitidamente marginal nos trabalhos de Genebra, mesmo nas intervenções das delegações que habitualmente insistem no seu tratamento, e que, desta feita, se resumem ao México e à URSS, para além do delegado da Espanha.

O tema central é a crise internacional e o aceso debate em torno da crise da SDN e da reforma ou da aplicação do Pacto. E a questão espanhola, quando abordada, é-o sobretudo a título exemplificativo, para ilustrar os efeitos da aplicação da política «realista» de apaziguamento por parte das principais potências ocidentais. Verifica-se isso, mesmo na alocução de Alvarez del Vayo, a 19 de Setembro, com um aviso particular aos negociadores de Munique: «Que ninguém pense na possibilidade de traficar o sangue de centenas de milhares de espanhóis mortos pela defesa do seu país, mas também pela defesa das democracias na Europa». E precisava: «A Espanha não é um naco de território com o qual seja possível acalmar por algum tempo a voracidade dos agressores $\rangle^{18}$. Prevenção não totalmente despropositada quando se sabe que

\footnotetext{
${ }^{18}$ Alvarez del Vayo, Compte rendu de la $19^{\text {ème }}$ séssion ordinaire..., $6^{\mathrm{eme}}$ s. pl., 19-9-1038.
} 
N. Chamberlain, em Munique, chega a sugerir para a Espanha uma solução idêntica à aplicada à Checoslováquia.

Dias depois, na sessão de 21 de Setembro, o primeiro-ministro Negrín produz uma intervenção de propósitos sobretudo tranquilizadores e conciliadores. Assegura que «uma vez eliminada a agressão estrangeira em Espanha posso assegurar que uma política de conciliação nacional, conduzida pela direcção firme e energética de um governo de autoridade, permitirá a todos os espanhóis esquecer estes anos de sofrimento e de crueldades». E, como demonstração da boa vontade do Governo espanhol e do seu desejo de eliminar qualquer pretexto que permitisse «pôr em dúvida o carácter nacional da causa por que se batem as armas da República», anuncia a retirada unilateral das Brigadas Internacionais, propondo a constituição de uma Comissão da SDN para fiscalizar a sua saída das zonas republicanas ${ }^{19}$. A proposta será adoptada na sessão plenária de 30 de Setembro, e as Brigadas Internacionais começarão a abandonar a Espanha a 15 de Novembro.

Negrín parecia aguardar uma contrapartida por parte dos franquistas ao seu gesto, como igualmente o sugere o seu discurso a 2 de Outubro seguinte pela rádio de Madrid, em que enuncia as condições republicanas para uma paz negociada com os revoltosos, que, aliás, as rejeitam. O que era natural: a 30 de Outubro os franquistas contra-atacam no Ebro e a 23 de Dezembro Yague lança o assalto final à Catalunha. Barcelona, sede de uma República exangue e já quase privada da ajuda externa, cai a 26 de Janeiro, ante a surpresa de um mundo «atónito com a rapidez do colapso, provocado, na verdade, pelo desgaste de homens e de material no Ebro» ${ }^{20}$.

A 28 e Fevereiro, a Grã-Bretanha e a França reconhecem o Governo de Franco, após os intensivos bons ofícios da diplomacia salazarista. Valência e Madrid são ocupadas a 30 de Março. Em 1 de Abril, Franco anunciava que a guerra terminara.

O Comité de Londres, num arremedo final do cínico drama da não intervenção, reúne-se no dia 20 de Abril para solenemente dar por terminada a sua missão e dissolver-se.

19 J.Negrín, idem, $8^{\text {ème }}$ s.pl., 21-9-1938.

${ }^{20}$ Hugh Thomas, A Guerra..., p. 467. 